\title{
Front Matter: Volume 8766
}

, "Front Matter: Volume 8766," Proc. SPIE 8766, Nanotechnology VI, 876601 (29 May 2013); doi: 10.1117/12.2031870

SPIE. Event: SPIE Microtechnologies, 2013, Grenoble, France 


\section{PROCEEDINGS OF SPIE}

\section{Nanotechnology VI}

\section{Rainer Adelung}

Editor

24-25 April 2013

Grenoble, France

Sponsored and Published by

SPIE

\section{Volume $\mathbf{8 7 6 6}$}


The papers included in this volume were part of the technical conference cited on the cover and title page. Papers were selected and subject to review by the editors and conference program committee. Some conference presentations may not be available for publication. The papers published in these proceedings reflect the work and thoughts of the authors and are published herein as submitted. The publisher is not responsible for the validity of the information or for any outcomes resulting from reliance thereon.

Please use the following format to cite material from this book:

Author(s), "Title of Paper," in Nanotechnology VI, edited by Rainer Adelung, Proceedings of SPIE Vol. 8766 (SPIE, Bellingham, WA, 2013) Article CID Number.

ISSN: 0277-786X

ISBN: 9780819495631

Published by

SPIE

P.O. Box 10, Bellingham, Washington 98227-0010 USA

Telephone +1 3606763290 (Pacific Time) · Fax +1 3606471445

SPIE.org

Copyright $@ 2013$, Society of Photo-Optical Instrumentation Engineers.

Copying of material in this book for internal or personal use, or for the internal or personal use of specific clients, beyond the fair use provisions granted by the U.S. Copyright Law is authorized by SPIE subject to payment of copying fees. The Transactional Reporting Service base fee for this volume is $\$ 18.00$ per article (or portion thereof), which should be paid directly to the Copyright Clearance Center (CCC), 222 Rosewood Drive, Danvers, MA 01923. Payment may also be made electronically through CCC Online at copyright.com. Other copying for republication, resale, advertising or promotion, or any form of systematic or multiple reproduction of any material in this book is prohibited except with permission in writing from the publisher. The CCC fee code is $0277-786 \mathrm{X} / 13 / \$ 18.00$.

Printed in the United States of America.

Publication of record for individual papers is online in the SPIE Digital Library.

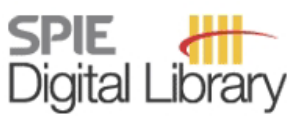

SPIEDigitalLibrary.org

Paper Numbering: Proceedings of SPIE follow an e-First publication model, with papers published first online and then in print and on CD-ROM. Papers are published as they are submitted and meet publication criteria. A unique, consistent, permanent citation identifier (CID) number is assigned to each article at the time of the first publication. Utilization of CIDs allows articles to be fully citable as soon as they are published online, and connects the same identifier to all online, print, and electronic versions of the publication. SPIE uses a six-digit CID article numbering system in which:

- The first four digits correspond to the SPIE volume number.

- The last two digits indicate publication order within the volume using a Base 36 numbering

system employing both numerals and letters. These two-number sets start with 00, 01, 02, 03, 04,

05, 06, 07, 08, 09, 0A, OB ... 0Z, followed by 10-1Z, 20-2Z, etc.

The CID Number appears on each page of the manuscript. The complete citation is used on the first page, and an abbreviated version on subsequent pages. Numbers in the index correspond to the last two digits of the six-digit CID Number. 


\section{Contents}

vii Conference Committee

ix An autonomous structural health monitoring solution (Plenary Paper) [8763-501]

C. A. Featherston, K. M. Holford, R. Pullin, J. Lees, M. Eaton, M. Pearson, Cardiff Univ. (United Kingdom)

$\mathrm{xv} \quad$ Biologically inspired large scale chemical sensor arrays and embedded data processing (Plenary Paper) [8763-502]

S. Marco, A. Gutiérrez-Gálvez, Univ. de Barcelona (Spain) and Institute for Bioengineering of Catalonia (Spain); A. Lansner, Kunliga Tekniska Högskolan (Sweden); D. Martinez, Ctr. National de la Recherche Scientifique (France); J. P. Rospars, Institut National de la Recherche Agronomique (France); R. Beccherelli, Consiglio Nazionale delle Ricerche (Italy); A. Perera, Univ. Politècnica de Catalunya (Spain); T. Pearce, Univ. of Leicester (United Kingdom); P. Vershure, Univ. Pompeu Fabra (Spain); K. Persaud, The Univ. of Manchester (United Kingdom)

\section{QUANTUM DOTS AND NANOWIRES}

876606 Dense chains of stacked quantum dots in Ge/Si heterostructures (Invited Paper) [8766-5] V. A. Yuryev, L. V. Arapkina, M. S. Storozhevykh, O. V. Uvarov, V. P. Kalinushkin, A. M. Prokhorov General Physics Institute (Russian Federation)

876607 Optical absorption cross section and quantum efficiency of a single silicon quantum dot [8766-6]

F. Sangghaleh, B. Bruhn, I. Sychugov, J. Linnros, Royal Institute of Technology (Sweden)

876609 Properties of individual GaP/ZnO core-shell nanowires with radial PN junction [8766-8] J. Novák, P. Eliáš, S. Hasenöhrl, A. Laurenciková, I. Vávra, Institute of Electrical Engineering (Slovakia); I. Novotný, J. Kováč, Slovenska Technicka Univ. (Slovakia); M. Mikulics, Forschungszentrum Jülich GmbH (Germany)

8766 OA Photoconductivity of catalyst-free grown aluminum nitride nanowires [8766-9] K. Teker, Istanbul Sehir Univ. (Turkey) and Frostburg State Univ. (United States); J. Otto, A. Siemann, Frostburg State Univ. (United States)

\section{CARBON NANOTUBES, GRAPHENE}

8766 OC Graphene nanoelectronics for high-frequency applications [8766-10] M. Dragoman, National Institute for Research and Development in Microtechnologies-IMT Bucharest (Romania) 
8766 OD Humidity sensing of an epoxy/MWCNT composite by electrical conductivity measurements [8766-12]

H. C. Neitzert, Univ. degli Studi di Salerno (Italy); A. Sorrentino, Institute for Composite and Biomedical Materials, CNR (Italy); L. Vertuccio, Univ. degli Studi di Salerno (Italy)

8766 OE Amorphous silicon-graphene anodes for lithium ion batteries [8766-13]

F. Farmakis, Democritus Univ. of Thrace (Greece); K. Alexandrou, Columbia Univ. (United States); C. Elmasides, Systems Sunlight S.A. (Greece); I. Kymissis, Columbia Univ. (United States); N. Georgoulas, Democritus Univ. of Thrace (Greece)

\section{NANOPARTICLES FOR BIOMEDICINE}

$8766 \mathrm{OH}$ Complexation of porphyrins with silver and zeolite nanoparticles [8766-17]

A. G. Gyulkhandanyan, Institute of Biochemistry (Armenia); R. K. Ghazaryan, Yerevan State Medical Univ. (Armenia); V. K. Gasparyan, H. O. Sargsyan, R. A. Madoyan,

A. G. Gyulkhandanyan, Institute of Biochemistry (Armenia); M. H. Paronyan, Science and Production Ctr. "Armbiotechnology" (Armenia); A. S. Stasheuski, V. N. Knyukshto, B. M. Dzhagarov, Institute of Physics (Belarus); G. V. Gyulkhandanyan, Institute of Biochemistry (Armenia)

876601 Effects of morphology on the emission of photons from GaN membranes fabricated using surface charge lithography [8766-25]

M. A. Stevens-Kalceff, The Univ. of New South Wales (Australia); I. M. Tiginyanu, Academy of Sciences of Moldova (Moldova) and Technical Univ. of Moldova (Moldova); V. Popa, T. Braniste, Technical Univ. of Moldova (Moldova); P. Brenner, Karlsruher Institut für Technologie (Germany)

\section{MICROFABRICATION}

8766 OL Diffractive microstructures based on metallic nanowires: a low cost solution for optical focusing devices [8766-21]

S. Zaiba, Lab. Interdisciplinaire de Physique CNRS, Univ. Grenoble (France), Univ. des Sciences et de la Technologie (Algeria), and The Univ. M'Hamed Bougara of Boumerdes (Algeria); T. Kouriba, Lab. Interdisciplinaire de Physique CNRS, Univ. Grenoble (France); O. Ziane, Univ. des Sciences et de la Technologie (Algeria); G. Vitrant, IMEP-LAHC, CNRS, Grenoble-INP (France); P. Baldeck, Lab. Interdisciplinaire de Physique CNRS, Univ. Grenoble (France)

$8766 \mathrm{OM}$ Influence of irregular growth of monoatomic steps during Si/Si(001) epitaxy on generation of surface defects [8766-22]

L. V. Arapkina, V. A. Yuryev, A. M. Prokhorov General Physics Institute (Russian Federation)

\section{POSTER SESSION}

876600 Calculation of nanoparticle surface shape instability development [8766-26]

T. N. Pogosyan, S. A. Chivilikhin, National Research Univ. of Information Technologies, Mechanics and Optics (Russian Federation) 
$87660 Q \quad$ Optical properties of silver nanoparticles coated by cyanine dyes molecular overlayers [8766-28]

N. A. Toropov, A. A. Starovoytov, N. B. Leonov, E. N. Kaliteevskaya, T. A. Vartanyan, National Research Univ. of Information Technologies, Mechanics and Optics (Russian Federation)

8766 OR Simulation of size distribution functions evolution in colloidal solutions of zinc oxide nanoparticles [8766-30]

A. V. Alfimov, E. M. Aryslanova, S. A. Chivilikhin, National Research Univ. of Information Technologies, Mechanics and Optics (Russian Federation)

8766 OT Modelling the initial stage of porous alumina growth during anodization [8766-32]

E. M. Aryslanova, A. V. Alfimov, S. A. Chivilikhin, National Research Univ. of Information Technologies, Mechanics and Optics (Russian Federation)

8766 OU Creation of entangled photons by two level atom trapped in one-dimensional nanocavity with weakly decaying resonance mode [8766-23]

V. Cheltsov, Moscow State Mining Univ. (Russian Federation)

8766 OW Gold nanoparticles embedded in organic/inorganic hybrid matrix: electrical and electrochemical behavior [8766-34]

S. D. F. C. Moreira, J. P. B. Silva, C. J. R. Silva, Univ. do Minho (Portugal); I. Capan, Institut Ruder Boškovic (Croatia); M. J. M. Gomes, M. F. M. Costa, Univ. do Minho (Portugal)

Author Index 


\section{Conference Committee}

Symposium Chair

Thomas Becker, EADS Innovation Works (Germany)

Symposium Cochairs

Christos Tsamis, National Center for Scientific Research Demokritos

(Greece)

Gerhard Krötz, University of Applied Sciences in Kempten (Germany)

Symposium Local Chair

Marc Belleville, CEA-Leti (France)

Conference Chair

Rainer Adelung, Christian-Albrechts-Universität zu Kiel (Germany)

Conference Cochair

Ion M. Tiginyanu, Academy of Sciences of Moldova (Moldova)

Conference Programme Committee

Sergey V. Gaponenko, B.I. Stepanov Institute of Physics (Belarus)

Mircea Dragoman, National Institute for Research and Development in Microtechnologies (Romania)

Jan Linnros, Royal Institute of Technology (Sweden)

James Lloyd-Hughes, University of Oxford (United Kingdom)

Hidenori Mimura, Shizuoka University (Japan)

Hadis Morkoç, Virginia Commonwealth University (United States)

Kornelius Nielsch, Universität Hamburg (Germany)

Thierry Pauporté, Ecole Nationale Supérieure de Chimie de Paris (France)

Andrei Sarua, University of Bristol (United Kingdom)

Marion A. Stevens-Kalceff, The University of New South Wales

(Australia)

Anatoly V. Zayats, King's College London (United Kingdom)

Session Chairs

1 Nanophotonics and Plasmonics I

Rainer Adelung, Christian-Albrechts-Universität zu Kiel (Germany) 
2 Nanophotonics and Plasmonics II

Rainer Adelung, Christian-Albrechts-Universität zu Kiel (Germany)

3 Quantum Dots and Nanowires

Ion M. Tiginyanu, Academy of Sciences of Moldova (Moldova)

4 Carbon Nanotubes, Graphene

Hidenori Mimura, Shizuoka University (Japan)

5 Nanoparticles for Biomedicine

Mircea Dragoman, National Institute for Research and Development in Microtechnologies-IMT Bucharest (Romania)

6 Microfabrication

Rainer Adelung, Christian-Albrechts-Universität zu Kiel (Germany) 